\title{
Is 're-mobilisation' nature restoration or nature destruction? A commentary
}

\author{
Irene Delgado-Fernandez ${ }^{1}$ (ID $\cdot$ Robin G. D. Davidson-Arnott ${ }^{2}$ - Patrick A. Hesp ${ }^{3}$
}

Received: 16 July 2019 / Revised: 25 October 2019 / Accepted: 28 October 2019 /Published online: 11 November 2019

(C) The Author(s) 2019

\begin{abstract}
Coastal dunes are experiencing increases in vegetation cover and reduced mobility levels in many sites around the world. Ecology-led approaches to coastal dune management perceive this change as 'undesirable' because the increase in plant cover leads to a reduction in partially vegetated to bare sand habitats and the species depending on them. This has generated a shift in the management paradigm where the objective is to revert this trend by intervening in the landscape, with actions ranging from reintroducing grazing and mowing, to mechanical removal of dune form and vegetation (dune 'rejuvenation'). In some cases, such as many coastal dunes in Britain, this has also led to low controls on visitor pressure and allowing/promoting human trampling as a 'natural' way to free up areas of bare sand. This commentary critically analyses the main principles (and terminology) underlying this relatively recent shift in management paradigm, and questions assumptions such as 'bare sand is good' and/or 'mobility is natural' in the context of dune evolutionary cycles and responses to abiotic and biotic drivers. We review the limitations and dangers of this approach and argue that it is not sustainable given the current climatic and environmental conditions, and that it can increase the risk of coastal erosion and force dune systems to deviate from adapting and changing to direct/indirect drivers. Finally, we present the benefits of a management approach that focuses on minimizing human impacts so that natural processes continue to occur.
\end{abstract}

Keywords Coastal dune management $\cdot$ Nature conservation $\cdot$ Coastal dune evolution

\section{Background and aim}

Over the past three decades there has been increasing recognition, particularly in Western Europe, of a relatively rapid increase in the vegetation cover of coastal dune systems, leading to a decline in the extent of mobile dunes and of bare sand cover (Provoost et al. 2011). This process has been described from many countries (Rhind et al. 2001; Jackson and Cooper 2011; Arens et al. 2013; Darke et al. 2013; Miot da Silva et al. 2013; Pye et al. 2014; Moulton et al. 2019; Osswald et al. 2019) and has in turn given rise to studies that attempt to

Irene Delgado-Fernandez

delgadoi@edgehill.ac.uk

1 Department of Geography and Geology, Edge Hill University, St Helens Rd, Orsmkirk, Lancashire L39 4QP, UK

2 Department of Geography, University of Guelph, 50 Stone Rd E, Guelph, ON N1G 2W1, Canada

3 BEADS Lab, College of Science and Engineering, Flinders University, Bedford Park, Adelaide, South Australia 5041, Australia determine the causes of this phenomenon and others which have focused on describing what effects the changes in vegetation and reduced dune mobility have had, or may have, on the dune ecology and geomorphology. In particular dune sealing (loosely defined here as the growth of vegetation across the front of, or within active dunes) has been identified as leading to a decrease in ecological diversity and species richness, as well as posing a threat to rare or endangered species (Smith 2009; Jones et al. 2010; Howe et al. 2010; Houston 2016). These species are mainly ones which are associated with bare sand areas, blowouts, deflation plains and basins, and dune slack wetlands. For example, there is commonly a suite of species (often rare) that occur in damp to seasonally flooded deflation areas/slacks, and these usually disappear once the deflation area/slack is fully stabilized or accretes to where flooding/ponding is less or does not occur (e.g. Esler 1970; Zoladeski 1991; Muñoz-Reinoso 2018). One result of this has been the development of various strategies to reverse the process of dune stabilization and/or sealing and to increase the proportion of bare sand cover leading to the creation of new landform units and/or remobilization of dunes (van Boxel et al. 1997; Arens et al. 2012; Murphy et al. 2019). 
These strategies are often described as rejuvenating the dunes or making them more dynamic with an implicit, or sometimes explicit, assertion that rejuvenated dunes are good and vegetated, static dunes are bad. Increasing dune mobility and decreasing vegetation cover has thus become an acceptable form of conservation restoration. There have been a wide range of actions aimed at the restoration of dunes of the Atlantic province of Europe, many of them funded through the EU and associated with LIFE Nature projects (Geelen et al. 2015; Houston 2016), and justified within the context of implementing the Habitats Directive (EU Council Directive 92/43/EEC on the Conservation of Natural Habitats and of Wild Fauna and Flora). Many of these projects include efforts to reduce vegetation cover through actions ranging from increased grazing, mowing, removal of invasive plant species, and the use of heavy machinery to clear vegetation and to produce artificial blowouts and slots connecting foredunes to inland dunes (Burton 2001; Hoffmann et al. 2001; Grootjans et al. 2002; Terlouw and Slings 2005; Rhind and Jones 2009; Arens et al. 2013; Millett and Edmondson 2013; Ruessink et al. 2018).

In Britain there have been similar concerns over dune stabilization and sealing (Rhind et al. 2013; Plassmann et al. 2010) and the impact on a number of species associated with bare sand areas such as the Natterjack Toad Epidalea calamita, Sand Lizard Lacerta agilis, and Northern Dune Tiger Beetle Cicindela hybrida (Edmonson and Velmans 2001). A number of scientists and organisations involved in conservation of sand dunes have embraced the concerns with dunes stabilization and sealing. Quite emotive language sometimes accompanies this concern, with fixed dunes described as 'over-stabilised' (e.g., Jones et al. 2010; Pye and Blott 2017), 'in need of help' (Natural Resources Wales 2014) or 'suffocated' (Natural England 2018) vs. mobile dunes which 'add to the character and diversity of the landscape' (Rhind and Jones 2009; p 16). This has led to management plans that have adopted the paradigm under which there is extensive human intervention designed to restore areas of bare sand and to increase sand mobility (e.g., DuneLIFE Dynamic Dunescapes 2018). In several dune fields in Wales and England this has included (or will include) the use of heavy equipment to bulldoze vegetation and establish corridors (essentially 'blowouts' or at least the deflation basin of a blowout) from the beach through the foredune so as to stimulate the transfer of sand from the coast inland (Fig. 1). Similar actions have taken place for some time in the Netherlands (Arens et al. 2013). Some of these actions have been funded through grants to agencies such as Natural England in collaboration with The National Trust and other partners, and personnel involved in management of individual dune systems seem to have accepted an approach that suggests that fixed dunes are somehow "bad" and that mobile dunes are "good".
In our view the widespread application of this paradigm goes against both our understanding of the functioning of coastal dune systems and the scientific basis for restoration of dunes as natural systems. We are concerned that many activities that are being carried out, or are proposed, have not received the level of critical examination that they should have and that potential shortcomings or adverse consequences are obscured as a consequence. Thus, the purpose of this paper is to describe what we see as the shortcomings and dangers in this approach to dune conservation and to suggest an alternate paradigm within which management of coastal dunes and dune restoration should be carried out. Our focus here is on the Atlantic dunes of western Europe and especially on those in England and Wales.

\section{Factors controlling dune evolution}

We begin with a reminder that Nature does not recognise 'good' and 'bad'. These are human values that may be driven, for example, by perception of beauty in a landscape or perceived threats to lives and to infrastructure. Coastal erosion may be a threat to human infrastructure and thus perceived as bad - but in nature it is simply a process. A large dune field with a mix of mobile and fixed dunes with bare patches may be regarded as good because of the contrasting views and wide range of flora and fauna, but it is just one manifestation of natural dune landscapes and no better or worse than any other. In fact, it usually represents just one stage of several possible evolutionary stages (Hesp 2013; de Groot et al. 2017; Pickart and Hesp 2019). Assigning human values to particular processes or landforms/ landscapes is not intrinsically unsound. However, when these values are used to justify a particular course of action in the name of dune restoration, rather than simply letting nature take its course, it needs to be clearly indicated. In doing so, the rationale for carrying out the particular form of human intervention or alteration can be incorporated into a thorough assessment of it. We will return to this theme later.

In planning the conservation and restoration of coastal dune systems it is important to recognise the critical role of abiotic properties (e.g. sediment size and mineralogy) and controlling processes (e.g., precipitation and temperature; wind and wave climate; littoral and dune sediment budgets) in determining the characteristics of dune form, dynamics and evolution (Arens et al. 2013). At a global scale, for example, in the absence of human intervention we can expect dunes of the arid Namibian coast or west African arid coastal regions (e.g. Western Sahara) to be characterized by high mobility and a large potential for the inland transfer of sand because high temperatures and low precipitation limit vegetation cover. Conversely, we can expect the dunes of the British coast to be characterized by low mobility and limited inland transport of sand because cool temperatures and high precipitation 
Fig. 1 Rejuvenation works at the seaward side of dune fields (a-b) and inside dune fields $(\mathbf{c}-\mathbf{e})$ in National Nature Reserves (NNR) in Wales, including (a) complete vegetation stripping (Kenfig NNR), (b) excavation of artificial notches (Newborough Warren NNR), and (c-d) creation of dune slacks and (e) artificial dunes with the sand extracted from excavation areas (Merthyr Mawr NNR). Images reproduced with permission of Natural Resources Wales and modified from Pye and Blott $(2013,2016 b)$ ) N Natural Resources Wales $(2013,2016)$
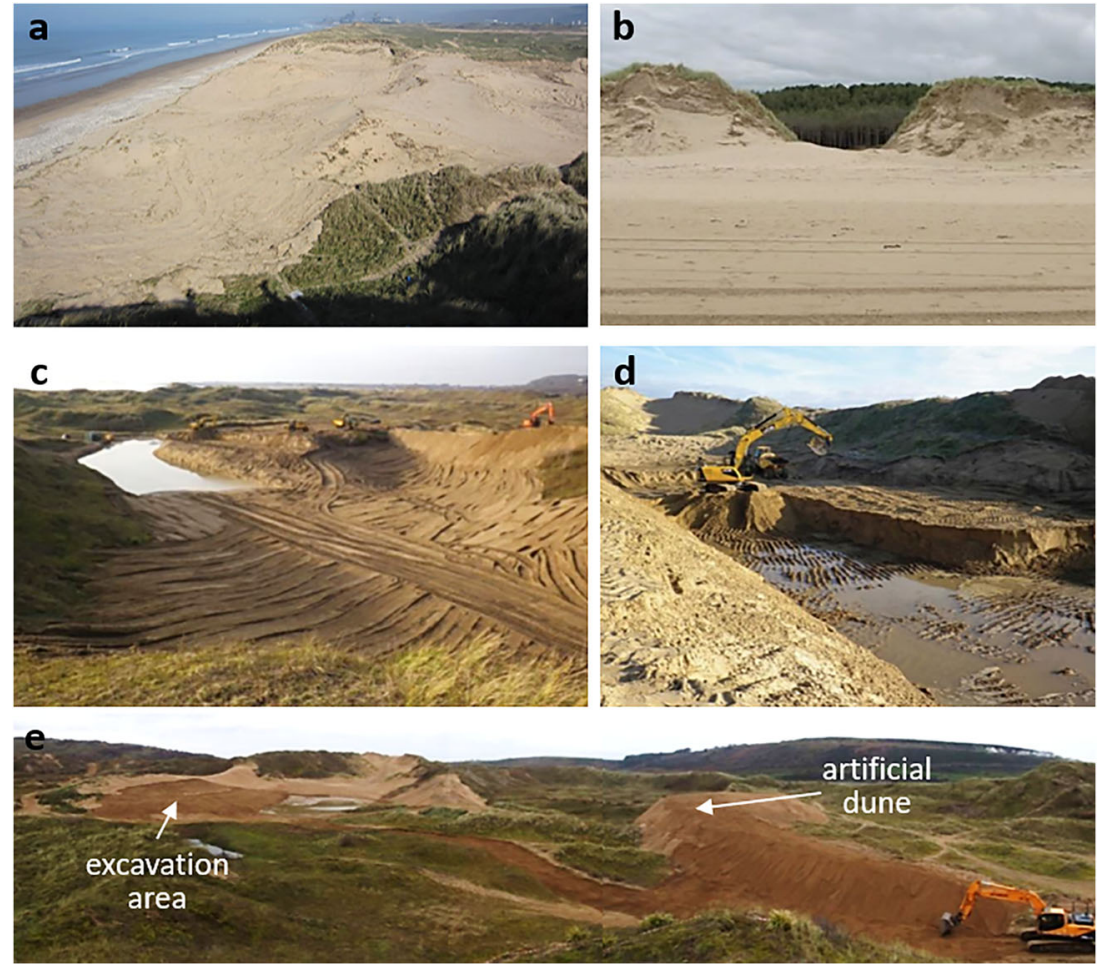

promote dense vegetation cover. These factors are also reflected in nebkha (discrete dune mound formed in an isolated plant) being the characteristic foredune in Morocco, Western Sahara and Mauritania (mean annual rainfall range $30-150 \mathrm{~mm}$ ) while a more laterally continuous vegetated foredune is characteristic of British coastal dunes. Locally, the potential for mobility is increased by large sediment supply and decreases with small sediment supply. Together, regional climate and sediment supply are important determinants of the spatial variability in coastal dunes at the global, regional and local scale (Hesp 2004; Pickart and Hesp 2019; García-Romero et al. 2019). They also control the potential range of mobility for coastal regions and they therefore set limits on what can be expected for a particular dune system under natural conditions. It is also recognized that the dynamics of coastal dunes will vary with the coastal setting and with the evolution of the coast and the dune field itself (BarrettMold and Burningham 2010) so that dunes of barrier islands, such as those on the east coast of North America and the west coast of Europe enclosing the Wadden Sea, are likely to be more dynamic compared to many British dunes because of the absence of stability provided by bedrock substrate and headlands, and the relatively regular occurrence of hurricanes and significant storm surge.

Abiotic factors are also important controls on the temporal variability of the dynamics of coastal dunes, and especially in the extent of bare sand and dune mobility. The magnitude and frequency of storm events controls the temporal pattern of foredune erosion and in turn this, together with the potential rate of sediment supply from the beach, controls foredune evolution and the volume of sand storage (Davidson-Arnott et al. 2018). Some of this variability in storminess may be global or regional in scale, and in western Europe may reflect broad climatic controls (Clarke and Rendell 2011; Clemmensen et al. 2014; Goslin et al. 2018). Variability may also be stochastic, reflecting the interaction of changing storm tracks, and coastal form and orientation (Masselink et al. 2016; Brooks et al. 2017; Castelle et al. 2017). On the East and Gulf coasts of the United States similar variability is associated with the random pattern of the landfall of tropical cyclones (hurricanes) (e.g., Lindner and Neuhauser 2018). The result of this is that on the Atlantic coast of Europe we can expect temporal variations in dune disturbance due to storms that may be synchronous over most, or all, of the region as well as disturbances due to individual storm events that will affect a limited section of the coast.

The interplay of abiotic processes and vegetation in dune systems is complex, particularly in the pioneer zone on the backshore and stoss slope of the foredune (Hesp 1991; Maun 2009). The rate of colonization and development of a continuous vegetation cover depends on the relationship between the rate of sediment supply and the ability of colonizing plants to withstand burial and in turn these will influence the form of the foredune and the rate at which sediment is transferred inland (Ruggerio et al. 2018). This is highlighted by the results of recent attempts to remove introduced Ammophila sp. from the west coast of North America (Pickart 2013; Pickart and Hesp 2019; Darke et al. 2016) and in New Zealand (Hilton 
et al. 2005; Hesp and Hilton 2013) which produced significant contrasts in the dune form and mobility between native pioneer species and the introduced Ammophila. Within dune fields disturbance may originate in various ways, including development of deflation basins, plains and slacks, and from the migration of slip faces associated with blowouts, parabolic and transgressive dunes (Hesp and Thom 1990) with the magnitude of disturbance varying with the height of the slip face and the rate of its migration (Hesp and Martinez 2007). Blowouts also commonly form as dunefields undergo natural vegetation colonization and stabilization (Hesp 2013; Hesp and Martinez 2007). Reactivation of vegetated dunefields by wind alone, for example, as a result of increased storminess, is much more difficult because of the hysteresis effect which requires much greater wind activity to disturb established vegetation than to maintain a vegetation-free surface (Tsoar 2005; Yizhaq et al. 2009). As a result, in humid environments such as that of western Europe, mobilization of dunes landward of the foredune is initiated primarily by disturbance of the foredune, either naturally or as a result of human activities, while disturbance originating from within the dunefield is commonly caused by human activities.

Additional to the processes described above, coastal areas are exposed to low frequency - high magnitude marine storms with the potential to 're-set' entire dune fields or portions of dune fields. Mathew et al. (2010) document an example on Prince Edward Island on the east coast of Canada where the impact of an intense storm in October 1923 generated a very large storm surge and eliminated the foredune along several tens of $\mathrm{km}$ of the shoreline of the NE coast, with wave action penetrating up to $500 \mathrm{~m}$ inland. It took nearly 40 years for a vegetated foredune to be restored, during which time large volumes of sand were transported inland and a new transgressive dune field was formed (Mathew et al. 2010; Walker et al. 2017). The growth of the foredune cut off most of the sediment supply to the interior and in the last 30 years the dune field has stabilized and is now largely vegetated. Stabilization of the inland dunes and growth of the foredune has produced a number of ponds and dune slacks which are still evolving. A century after the initial disturbance, the dune system has undergone continuous transformation and the composition and relative abundance of the biotic components have evolved in conjunction with the abiotic components. This has occurred with limited human intervention and presently management by PEI National Park is simply to allow the system to continue to evolve naturally in response to changing sediment budget and rising sea level.

\section{Anthropogenic activities and traditional approaches to dune restoration}

There are many studies that have documented the degree to which human activities have reduced the number and area of sand dune systems and have altered the vegetation cover and species of flora and fauna present in dune systems in the UK (e.g. Ranwell 1960a, b; Rhind et al. 2001), in Europe (e.g., Provoost and van Landuyt 2001; Paskoff 2001; Malavasi et al. 2013; Calvão et al. 2013) and elsewhere (e.g. Seabloom et al. 2006; Zarnetske et al. 2010). These alterations have resulted from many actions, including construction of buildings on dune systems, recreational pressures, shore protection structures, introduction and subsequent spread of invasive species, grazing, and many others (Nordstrom 2008). They have also directly affected sand transport and supply to the beach, from the beach to the foredune, and from the foredune inland (Hilton et al. 2006). In response to this, the traditional approach to dune management and restoration in the last few decades of the twentieth century was to protect existing systems from further development, remove infrastructure such as buildings, caravan parks and roads, and to reduce the effects of humans on the dune vegetation by development of paths, boardwalks and fencing, and reduced grazing of livestock (e.g., Ley et al. 2007; Nordstrom and Jackson 2013; Rosario Acosta et al. 2013). This was done within a paradigm of restoring natural functioning of the dune system - particularly the foredune system - and of revegetating bare areas produced by human activities using typical pioneer plants such as marram. In some cases, revegetation of areas in the dune field landward of the foredune involved the planting of trees to stop the migration of sand onto agricultural fields, roads, buildings and other human infrastructure. This was done with the aim of protecting infrastructure and was a result of poor management leading to the destruction of dune vegetation by trampling and the introduction of invasive species to deal with the consequences of it (e.g. marram grass in North America, Australia and New Zealand; Acacia in South Africa; pine trees in Spain and other European countries). Over time, these exotic species artificially stabilized and/or created new dunes resulting in widespread problems including the elimination of native flora, with many current de-vegetation programs now aiming at eradicating introduced species and hence reversing previous management decisions. Alternatively, good management practices involving the removal of artificial stressors and sustainable environmental uses would have allowed the system to seal naturally and hence prevented the need for planting trees.

\section{Shift in paradigm and critical examination of dune rejuvenation objectives}

In western Europe since the 1990s a new paradigm has appeared which contrasts in many ways with the traditional one. The object of dune management and restoration under this paradigm is to reduce the proportion of dune covered by vegetation and to increase the area of bare sand and dune mobility. Measures taken to accomplish this include restoration of 
grazing, reintroduction of rabbits, mowing of vegetation in dunefields and mature dune slacks and deflation basins/plains, mechanical uprooting of scrub, bulldozing of slots through the foredune and the creation of artificial blowouts in the dunefield. In Britain one example of the adoption of this approach is the awarding of a $£ 4.3$ million grant for dune restoration to be managed by Natural England in partnership with Plantlife, The National Trust and the Wildlife Trusts. According to the press release accompanying the award (Natural England 2018):

Healthy sand dunes with moving sand are a sanctuary for endangered plants and animals like the natterjack toad, dune gentian and sand lizard. However, these habitats are currently being smothered and fixed by a tide of invasive non-native plants turning it into scrubland. The scheme will: 1) Deliver a programme of removal of invasive species to rebalance the natural processes of dune colonisation; 2) Restore sand dunes and dune slacks; 3) Create bare sand patches by turf stripping and sand scraping; 4) Encourage more people to access and enjoy dunes and take part in their conservation.

The removal of introduced invasive species such as Rosa rugosa and Hippophae rhamnoides (Smith 2009; Richards and Burningham 2011) can be justified as part of an overall objective of restoring the operation of natural processes to the dune systems. However, the other three objectives all involve human interventions which will alter the landscape and interfere with the natural controlling processes or drivers. Thus, 2) "Restoring sand dunes and dune slacks" involves the use of heavy machinery to cut slots in foredunes, the creation of artificial blowouts and the excavation of dunes down to the water table to create dune slacks. Similarly, 3) "Creating bare sand patches..." is accomplished by mechanically stripping vegetation and turf, or by introducing grazing by domestic animals. Finally, 4) "Encouraging people to access and enjoy dunes..." is actually a call to allow visitors to trample the dune vegetation and create random bare sand pathways. This is all guided by a desire to 'restore' the dunes to an idealised, more 'dynamic', form that is intended to provide a landscape that will: a) maximise biodiversity within each dune system; and b) will provide within it more habitat space geared to promoting the survival of a small number of species of flora and fauna. The latter are primarily those associated with bare sand areas, and commonly existing due to the proximity of the water table, that have been identified as being rare and endangered. The enthusiasm with which this paradigm has been adopted is epitomised in a post on the web site (https://www. gov.uk/government/news/threatened-sand-dunes-given-anew-lease-of-life) with introductory paragraph stating "Sand dunes across England are set for a golden future" (our emphasis) accompanying the funding announcement to the effect that:

Re-enlivening the sand dunes - much of them now suffocated under a blanket of thick grass and scrub - is urgent if we are to save dune flowers such as the plucky little fen orchid from extinction. Purple milk-vetch and dune gentian, two other rare dune gems, face an increasingly uncertain future without the help of this exciting project. And the really great news is that everybody who visits the dunes can make a difference: we know now that trampling feet is a great way to free up space for rare plants.

One can argue that creating bare patches within vegetated dunes may increase the number of plant, animal and insect species present, i.e. increasing the biodiversity within that system, and that removing late successional vegetation from dune slacks, or creating entirely new ones will do the same thing. This has occurred to an extent in some cases (e.g. Grootjans et al. 2002; Murphy et al. 2019) but the jury remains out in others (Ruessink et al. 2018). However, there is no need for every dune system to have every possible form of flora and fauna. Instead, in a natural system, biodiversity is dependent on the interaction of the abiotic and biotic elements and the resulting biodiversity is neither good nor bad - it is just the outcome of that interaction. Moreover it will change over time as a result of both internal evolution and external forcing. As we noted earlier, there are sufficient differences in the abiotic properties, processes and evolution of the dune landscape in the coastal dunes of Britain and Western Europe to produce a wide range of habitats and an equally wide range of flora and fauna. The removal of introduced species will aid in the restoration of the natural functioning of these systems, thus enhancing the overall biodiversity in the region. As a result, we would argue that there is no scientific justification for any further interventions to alter the functioning of dune systems. Because of the present climate of England and Wales it is likely that vegetation colonization and stabilization of dunes will continue, and there will therefore be an ongoing requirement for continued human intervention to maintain the areas of bare sand and the transfers of sand from the beach and foredune to the interior (Arens and Geelen 2006; DelgadoFernandez et al. 2019). In effect there will still be significant human impact on the natural system - just of a different sort. Maintaining a status that is not natural (i.e., not adjusted to contemporary environmental conditions) can turn coastal dune management into expensive habitat engineering.

The second set of drivers of intervention to promote the development of dynamic dunes are related to perceived needs to save particular plants, animals and insects that are seen as rare and whose existence may be threatened by the absence of bare sand in the dune system (Rhind and Jones 1999; Howe 
et al. 2010; Wouters et al. 2012). Again, this seems to be a case where human perceptions of the value attached to a particular species, in this case because it is 'rare', have led to the development of a set of actions that are intended to manipulate a whole ecosystem so as to favor the habitat required for these particular few species. This appears to have occurred without sufficient consideration for the impact it may have on other plant and animal communities (e.g., Zarnetske et al. 2010) and whether it is sustainable under existing abiotic conditions (Delgado-Fernandez et al. 2019). In particular, it seems that the proposed actions are designed to replicate conditions from decades ago that came into existence primarily because of human disturbance of dune vegetation. The increased dune sealing and/or vegetative stabilization as a result of a reduction in anthropogenic disturbance has led to a reduction in bare sand and thus it can be expected that there is a reduction in habitat suitable for bare-sand specialists. However, as noted earlier, taken as a whole, natural dune environments will always have some areas of bare sand, especially in the foredune zone, and the areas will likely expand and contract temporally and spatially as a result of the timing and magnitude of natural disturbance and coastal evolution.

If dune management is focused on increasing the proportion of dune systems that are largely free of human impacts and are able to evolve naturally then this is likely to have the greatest benefit for all dune species. Manipulating the system to favor a few chosen species runs the risk of endangering the system as a whole; and this is particularly true of suggestions to permit visitors to the beach and dune system to run and trample all over the dunes. The potential for habitat destruction is especially important for the backshore, embryo or incipient dune and the toe of the stoss slope of the foredune where the pioneer perennial and annual plant species are most vulnerable to trampling. Increases in trampling intensity can lead to long lasting ecosystem changes including a decrease in species diversity, alterations to the proportion of different species, and dissemination of invasive species as people's clothing and dog's hair transport seeds from nearby gardens and other locations (Hesp et al. 2010; Malavasi et al. 2016; PérezMaqueo et al. 2017). Furthermore, little consideration is being given to concerns arising from dune rejuvenation leading to increased coastal erosion (Lindell et al. 2017). Vegetation reduces wave run up dune erosion by approximately $40 \%$ (Feagin et al. 2019), with vegetated foredunes having poststorm sediment volumes that are larger than dunes with no vegetation (Maximiliano-Córdova et al. 2019). The presence of plants decreases scarp retreat by over $30 \%$, and mature roots double the time for dune structural failure and increase the shear required to erode sediment by $180 \%$ (Sigren et al. 2014).

Finally, some reports have suggested that sealing and stabilization of the dunes and the reduction of sand transfers inland will somehow make the dune system more vulnerable to destruction due to sea level rise (Rhind and Jones 2009). There is no geomorphological basis for this that we are aware of. Relative sea level rise will inevitably lead to more frequent erosion of the foredune during storms and enhanced landward transfers over the dune crest and as a result of blowout development (Davidson-Arnott 2005; Pye and Blott 2016a; Walker et al. 2017). However, artificial enhancement of inland sand transfers may leave the foredune more vulnerable to enhanced scarping and/or overwash and thus to destruction of inland habitats that are protected by the presence of the foredune. If natural dune processes are permitted to operate without intervention, the only management required is to ensure that there is sufficient area inland for dune translation or migration to take place - i.e., that coastal squeeze does not occur (Pontee 2013).

\section{Re-focusing coastal dune management}

The changing temporal and spatial nature of coastal dune systems has been captured in many studies (e.g., Nordstrom et al. 1990; Sherman and Bauer 1993; Maun 2009; Reed et al. 2009; Davidson-Arnott et al. 2019; Hesp and Walker 2013; Hesp 2013; Walker et al. 2017) but we select the following reflection by Rhind et al. (2001, p.377):

... At Newborough Warren there is compelling evidence that the vegetation cover has been through major phases of change and that at some time in the future, it may undergo a complete reversal of its current trend. Are we ever therefore justified in attempting to either retard or reverse this process of change? Such action has certainly been a general characteristic of past conservation management. When dunes were more mobile there were attempts to stabilize them; now the emphasis is often more on destabilization. Furthermore, when dealing with an evolving system should any given point on the spectrum of change be regarded as optimal in terms of conservation value? For example, was Newborough as Ranwell knew it in the 1950s any better or worse than it is today? If there is a lesson to be learnt here, it is that sand dune conservation has to embrace the fact that flux is an integral part of the system. More emphasis should therefore be devoted towards assessing the direction of the current trends, and on extending the timescales over which future management is considered.

There are many forms of dune restoration and certainly no shortage of coastal dunes to restore (Martínez et al. 2013). But 'restoration' invites the question of 'restoration to what?' and hence implies consideration of aspects such as what is expected of the natural system (Elliott et al. 2007). Following on Rhind et al's arguments above, how do we choose what to 
restore dunefields to? Studies can tell us about landform evolution and morphologies of some dune fields formed over the past 10,000 years to the present ... so which point in time do we select as some idealised dune state? Labelling a particular dune evolutionary stage (e.g., mobility) as 'natural' or 'desirable' seems arbitrary and vague, especially within the context of anthropogenic land uses of European dunes going back hundreds of years.

Instead, we have abundant knowledge on the effect of human impacts on coastal dunes and their degradation as a result of recreation and trampling, industrial and commercial uses, waste disposal, invasive species, and land uses such as urban infrastructure, agriculture, farming, and mining, amongst others (Gómez-Pina et al. 2002; Nordstrom 2003; Zunzunegui et al. 2012; Cabrera-Vega et al. 2013; Calvão et al. 2013; Lithgow et al. 2013). Studies indicate that the best route to nature restoration is the removal of stressors that cause artificial system changes, and implementation of actions that prevent other stressors from operating so habitats can recover naturally (Elliott et al. 2007). Thus, we suggest that coastal dune management should focus on controlling human impacts, not natural processes. This might be complex in heavily urbanised locations, but removing stressors from natural and semi-natural environments can be relatively inexpensive, and may simply begin by preventing unnecessary landscape interventions (e.g., rejuvenation, grazing, mowing, etc.) and promoting correct public attitudes and sustainable recreation (e.g., using designated paths, virtual fencing and information stalls/guided tours) (Fig. 2).

\section{Concluding remarks}

Interfering with the evolution of coastal dunes to maintain artificial levels of bare sand leads to systems that are not natural (i.e., not attuned to the ambient conditions), and, in fact, fight against natural evolutionary processes taking place in the dunefields. Aside from efforts to remove, and at the very least, control the further spread of invasive species, there is no evidence that removing native dune grasses and mature vegetation is restoration but rather landscaping to create 'desirable' dune habitats. Pioneer dune species tend to colonize more mobile sections of dune fields with other species following and vegetation succession driving the system towards mature stages characterised by low dune mobility levels. Perceiving low mobility as 'bad' in these natural scenarios is a type of perspective because the presence / absence of particular species is simply a result of habitat evolution and dune dynamic change. Instead, we propose that coastal dune management should focus on protecting coastal dunes by minimizing human impacts and controlling visitor pressure, so that dunes can evolve naturally.

The implementation of the Habitats Directive seems to have been conducted without careful consideration of risks to coastal erosion or the changing nature of coastal dunes as a result of both abiotic and biotic drivers. It is also worth noting that many of the coastal dune management experiences shared across EU countries include examples from the Netherlands (see Houston et al. 2001). The Dutch have a clear driving need to manage or intervene in their dunes, in particular maintaining them as dykes and defense structures, and to prevent a re-occurrence of the 1953 storm surge event. Their activities are therefore not often a good example to follow because the scenarios for coastal dune management in Europe are much more diverse and the context varies markedly depending on the particular history and drivers at each dune field.

To our knowledge, while nitrogen aerosol deposition has increased due to industrial activity in parts of Europe (Ten Harkel 1996; van Boxel et al. 1997; Grootjans et al. 2004; Stevens et al. 2010), and the rabbit populations have been reduced (Ranwell 1960b), there is little evidence suggesting

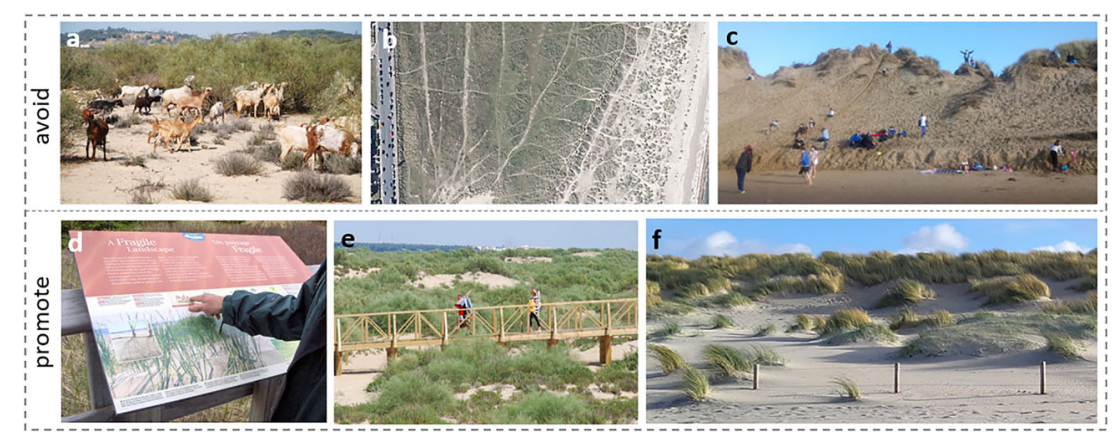

Fig. 2 Examples of 'mismanaged' (above) vs. managed (below) recreation and land uses. Anthropogenic disturbances include grazing (a - El Rompido, Spain) and multiple track creation and pedestrian trampling (b - Great Yarmouth, E England; $\mathbf{c}$ - Sefton, NW England). Managed recreation includes the use of information stalls and guided tours (d - Greenwich, Canada), elevated boardwalks and designated beach access points (e - El Rompido, Spain), and virtual fencing (f Zandmotor, The Netherlands). Images by J. Bautista Gallego (a \& e; University of Sevilla, Spain); N. O'Keeffe (c; Edge Hill University, UK); I. Delgado-Fernandez (d \& f; Edge Hill University, UK); and Aerial Digimap (C) Getmapping Plc (b) 
that the trend towards vegetation colonization and stabilization of dunes and dune sealing observed over the last few decades is also not natural. Indirect human-induced changes such as nitrogen deposition could be aiding in dune stabilization, but the extent to which these have played a significant role remains to be clearly established (Aggenbach et al. 2017). As Kooijman et al. (2017) detail, the magnitude of nitrogen deposition varies considerably within different countries of western Europe and differs also between sites close to the sea and those inland. In addition, the impact of nitrogen on dune systems varies considerably in relation to factors such as the carbonate content of sands and the extent of activities such as grazing of livestock. Thus, we suggest that any dune management plan that includes proposals to enhance dune mobility artificially because of recent vegetative growth should demonstrate that a mobile dune system would exist under a lowered nitrogen regime and natural conditions. Natural stabilization of dunefields is also now common across the southern hemisphere (and likely not just due to rabbit control as it has occurred where rabbits were never present).

Although a range of human-induced changes such as warmer temperatures and modified precipitation regimes have been cited as potential global drivers for dune sealing (Jackson et al. 2019) there is no evidence that these are playing a primary role at the regional or local scale (Moulton et al. 2019; Delgado-Fernandez et al. 2019; Rodgers et al. 2019). Instead, the consequences of direct human actions leading to artificial dune landscapes (from planting pine trees and widespread issues associated to invasive species to destroying native dune grasses via trampling or with machinery) are well-understood and can be prevented. In our view, the default approach to dune conservation should begin with no intervention and then any proposed artificial disturbances would require a clear assessment of the potential impact of the intervention on the whole dune system with a view to minimize such impact. We acknowledge that some species are important from an ecological point of view and that there may be areas where local vegetation removal could be considered in order to preserve flora and/or fauna that are rare and endangered regionally. Again, we would argue that this situation should occur rarely and should only be implemented after thorough evaluation of the evidence and potential impacts. It is one thing to act against habitat destruction due to human activities (e.g., habitat encroachment due to urbanization or the introduction of invasive species) and quite a different one is to act against habitat change due to the evolution of the system (as in many sites in Britain, where native grasses are removed to artificially inject 'dynamism' into the landscape). Attempting to 'reverse' natural trends to provide past 'desirable' conditions because of a set of rare species forces the landscape to become unattuned to ambient conditions. Dunes change to adapt to environmental conditions and this adaptability is directly linked to their resilience (Kombiadou et al. 2019). While some species might be key from an ecology point of view there is a need to consider the bigger picture and investigate the consequences of displacing the system from its evolutionary path, especially in the context of recent evidence suggesting that rejuvenation can be short-lived and hence unsustainable (Arens et al. 2013; Rodgers et al. 2019) and that it can increase the risk of coastal erosion (Lindell et al. 2017).

In short, we conclude that the primary principle of coastal dune management should be management of people - not management of natural processes.

Acknowledgements This work is a contribution to Edge Hill University's IKEF programme (grant 1IKIDE18). The authors are grateful to Nicholas O'Keeffe for comments on earlier material. PH thanks the BEADS lab and Flinders University for support. IDF thanks Graham Weaver and Natural England staff for critical discussion and on-going dialogue. Thanks to Jeff Ollerhead and an anonymous reviewer for comments on the submitted draft.

Open Access This article is distributed under the terms of the Creative Commons Attribution 4.0 International License (http:// creativecommons.org/licenses/by/4.0/), which permits unrestricted use, distribution, and reproduction in any medium, provided you give appropriate credit to the original author(s) and the source, provide a link to the Creative Commons license, and indicate if changes were made.

\section{References}

Acosta RT, Jucker T, Prisco I, Santoro R (2013) Passive recovery of Mediterranean coastal dunes following limitations to human trampling. In: Martínez ML, Gallego-Fernández JB, Hesp PA (eds) Restoration of coastal dunes, Springer series of environmental management. Springer-Verlag, Berlin, pp 187-198

Aggenbach CJ, Kooijman AM, Fujita Y, van der Hagen H, van Til M, Cooper D, Jones L (2017) Does atmospheric nitrogen deposition lead to greater nitrogen and carbon accumulation in coastal sand dunes? Biol Conserv 212:416-422

Arens SM, Geelen LHWT (2006) Dune landscape rejuvenation by intended destabilization in the Amsterdam water supply dunes. J Coast Res 22:1094-1107

Arens SM, Mulder JP, Slings QL, Geelen LH, Damsma P (2013) Dynamic dune management, integrating objectives of nature development and coastal safety: examples from the Netherlands. Geomorphology 199:205-213

Arens SM, Slings QL, Geelen LHWT, Van der Hagen HGJM (2012) Restoration of dune mobility in the Netherlands. In: Martínez ML, Gallego-Fernández JB, Hesp PA (eds) Restoration of coastal dunes, Springer series on environmental management. Springer-Verlag, Berlin, pp 107-124

Barrett-Mold C, Burningham H (2010) Contrasting ecology of prograding coastal dunes on the northwest coast of Ireland. J Coast Conserv 14:81-90

Brooks SM, Spencer T, Christie EK (2017) Storm impacts and shoreline recovery: mechanisms and controls in the southern North Sea. Geomorphology 283:48-60

Burton P (2001) Grazing as a management tool and the constraints of the agricultural system: a case study of grazing on Sandscale Haws Nature Reserve, Cumbria, northwest England. In: Houston JA, Edmondson SE, Rooney PJ (eds) Coastal dune management. Shared experience of European conservation practice. Proceedings of the European Symposium Coastal Dunes of the Atlantic 
Biogeographical Region, Southport, NW England, September 1998, Liverpool University Press, pp 80-85

Cabrera-Vega LL, Cruz-Avero N, Hernández-Calvento L, HernándezCordero AI, Fernández-Cabrera E (2013) Morphological changes in dunes as an indicator of anthropogenic interferences in arid dune fields. J Coast Res 65:1271-1277

Calvão T, Pessoa MF, Lidon FC (2013) Impact of human activities on coastal vegetation-a review. Emir J Food Agr 25:926-944

Castelle B, Bujan S, Ferreira S, Dodet G (2017) Foredune morphological changes and beach recovery from the extreme 2013/2014 winter at a high-energy sandy coast. Mar Geol 385:41-55

Clarke ML, Rendell H (2011) Atlantic storminess and historical sand drift in Western Europe: implications for future management of coastal dunes. J Coast Conserv 15:227-236

Clemmensen LB, Hansen KWT, Kroon A (2014) Storminess variation at Skagen, northernmost Denmark since AD 1860: relations to climate change and implications for coastal dunes. Aeolian Res 15:101-112

Darke IB, Eamer JBR, Beaugrand HER, Walker IJ (2013) Monitoring considerations for a dynamic dune restoration project: Pacific rim National Park Reserve, British Columbia, Canada. Earth Surf Process Landf 38:983-993

Darke IB, Walker IJ, Hesp PA (2016) Beach-dune sediment budgets and dune morphodynamics following coastal dune restoration, Wickaninnish dunes, Canada. Earth Surf Proc Land 41:1370-1385

Davidson-Arnott RGD (2005) Conceptual model of the effects of sea level rise on sandy coasts. J Coast Res 21:1166-1172

Davidson-Arnott RGD, Bauer BO, Houser C (2019) Introduction to coastal processes and geomorphology, 2nd edn. Cambridge University Press, Cambridge, 523 pp

Davidson-Arnott RGD, Hesp PA, Ollerhead J, Walker I, Bauer BO, Delgado-Fernandez I, Smyth TAG (2018) Sediment budget controls on foredune height: comparing simulation model results with field data. Earth Surf Proc Land. https://doi.org/10.1002/esp.4354

De Groot AV, Oost AP, Veeneklaas RM, Lammerts EJ, van Duin WE, van Wesenbeeck BK (2017) Tales of island tails: biogeomorphic development and management of barrier islands. J Coast Conserv 3:409419

Delgado-Fernandez I, O'Keeffe N, Davidson-Arnott RGD (2019) Natural and human controls on dune vegetation cover and disturbance. Sci Total Environ 672:643-656

DuneLIFE - Dynamic Dunescapes (2018) LIFE17 NAT/UK/000570. $\mathrm{http} / /$ ec.europa.eu/environment/life/project/Projects/index.cfm? fuseaction $=$ search.dspPage \&n_proj_id $=6812$

Edmonson SE, Velmans C (2001) Public perception of nature management on a sand dune system. In: Houston JA, Edmondson SE, Rooney PJ (eds) Coastal dune management. Shared experience of European conservation practice. Proceedings of the European Symposium Coastal Dunes of the Atlantic Biogeographical Region, Southport, NW England, September 1998, Liverpool University Press, p 206-2018

Elliott M, Burdon D, Hemingway KL, Apitz SE (2007) Estuarine, coastal and marine ecosystem restoration: confusing management and science-a revision of concepts. Estuar Coast Shelf Sci 74:349-366

Esler AE (1970) Manawatu sand dune vegetation. Proc NZ Ecol Soc 17(17):41-46

Feagin RA, Furman M, Salgado K, Martínez ML, Innocenti RA, Eubanks K, Figlus J, Huff TP, Sigren J, Silva R (2019) The role of beach and sand dune vegetation in mediating wave run up erosion. Estuar Coast Shelf Sci 219:97-106

García-Romero L, Hesp PA, Peña-Alonso C, Miot da Silva G, Hernández-Calvento L (2019) Climate as a control on foredune mode in southern Australia. Sci Total Environ 694:133768

Geelen L, Salman A, Kuipers M (2015) Daring solutions for Natura 2000 challenges. Conference Report Dynamic Dunes, October 2015, Zandvoort, The Netherlands
Gómez-Pina G, Muñoz-Pérez JJ, Ramírez JL, Ley C (2002) Sand dune management problems and techniques, Spain. J Coast Res 36:325333

Goslin J, Fruergaard M, Sander L, Gałka M, Menviel L, Monkenbusch J, Thibault N, Clemmensen LB (2018) Holocene centennial to millennial shifts in North-Atlantic storminess and ocean dynamics. Nature Sci Rep 8:12778

Grootjans AP, Adema EB, Bekker RM, Lammerts EJ (2004) Why young coastal dune slacks sustain a high biodiversity. In: Martinez ML, Psuty NP (eds) Coastal dunes, ecology and conservation. Springer, Berlin, pp 85-101

Grootjans AP, Geelen HWT, Jansen AJM, Lammerts EJ (2002) Restoration of coastal dune slacks in the Netherlands. Hydrobiologia 478:181. https://doi.org/10.1023/A:1021086832201

Hesp PA (1991) Ecological processes and plant adaptations on coastal dunes. J Arid Environ 21:165-191

Hesp PA (2004) Coastal dunes in the tropics and temperate regions: location, formation, morphology and vegetation processes. In: Martinez ML, Psuty NP (eds) Coastal dunes, ecology and conservation. Springer, Berlin, pp 29-49

Hesp PA (2013) Conceptual models of the evolution of transgressive dunefield systems. Geomorphology 199:138-149

Hesp PA, Hilton MJ (2013) Restoration of foredunes and transgressive dunefields: case studies from New Zealand. In: Martínez ML, Gallego-Fernández JB, Hesp PA (eds) Restoration of coastal dunes, Springer series on environmental management. Springer-Verlag, Berlin, pp 67-92

Hesp PA, Martinez M (2007) Disturbance processes and dynamics in coastal dunes. In: Johnson EA, Miyanishi K (eds) Plant disturbance ecology: the process and response. Academic, pp 215-247

Hesp PA, Schmutz P, Martinez MM, Driskell L, Orgera R, Renken K, Revelo NAR, Orocio OAJ (2010) The effect on coastal vegetation of trampling on a parabolic dune. Aeolian Res 2:105-111

Hesp PA, Thom BG (1990) Geomorphology and evolution of active transgressive dunefields. In: Nordstrom KF, Psuty NP, Carter RWG (eds) Coastal dunes: form and process. Wiley, Chichester, pp 251-288

Hesp PA, Walker IJ (2013) Coastal dunes. In: Lancaster N, Baas ACW, Sherman DJ (eds) Treatise on geomorphology. Elsevier Inc., pp 328-355

Hilton M, Duncan M, Jul A (2005) Processes of Ammophila arenaria (marram grass) invasion and indigenous species displacement, Stewart Island, New Zealand. J Coast Res 21:175-185

Hilton M, Harvey N, Hart A, James K, Arbuckle C (2006) The impact of exotic dune grass species on foredune development in Australia and New Zealand: a case study of Ammophila arenaria and Thinopyrum junceiforme. Aust Geogr 37(3):313-334

Hoffmann M, Cosyns E, Deconinck M, Lamoot I, Zwaenepoel A (2001) Donkey diet in a Flemish coastal dune area in the first year of grazing. In: Houston JA, Edmondson SE, Rooney PJ (eds) Coastal dune management. Shared experience of European conservation practice. Proceedings of the European Symposium Coastal Dunes of the Atlantic Biogeographical Region, Southport, NW England, September 1998. Liverpool University Press, pp 95-107

Houston JA (2016) Summary report, LIFE platform meeting: restoration of sand dune habitats, June 2016, Zandvoort, The Netherlands

Houston JA, Edmondson SE, and Rooney PJ (eds) (2001) Coastal dune management. Shared experience of European conservation practice. Proceedings of the European symposium coastal dunes of the Atlantic biogeographical region, Southport, NW England, September 1998. Liverpool University Press

Howe MA, Knight GT, Clee C (2010) The importance of coastal sand dunes for the terrestrial invertebrates in Wales and the UK, with particular reference to aculeate bees, wasps and ants. J Coast Conserv 14:91-102 
Jackson DWT, Cooper JAG (2011) Coastal dune field in Ireland: rapid response to climatic change. J Coast Res 64:293-297

Jackson DWT, Costas S, González-Villanueva R, Cooper JAG (2019) A global 'greening' of coastal dunes: an integrated consequence of climate change? Global Planet Change 182:103026

Jones MLM, Sowerby A, Rhind PM (2010) Factors affecting vegetation establishment and development in a sand dune chronosequence at Newborough Warren, North Wales. J Coast Conserv 14:127-137

Kombiadou K, Costas S, Carrasco AR, Plomaritis TA, Ferreira Ó, Matias A (2019) Bridging the gap between resilience and geomorphology of complex coastal systems. Earth-Sci Rev 198:102934

Kooijman AM, van Til M, Noordijkc M, Remke E, Kalbitz K (2017) Nitrogen deposition and grass encroachment in calcareous and acidic Grey dunes (H2130) in NW-Europe. Biol Conserv 212:406-415

Ley C, Gallego-Fernández JB, Vidal C (2007) Manual de restauración de dunas costeras. Ministerio de medio ambiente, Spain

Lindell J, Fredriksson C, Hanson H (2017) Impact of dune vegetation on wave and wind erosion: a case study at Ängelholm Beach, South Sweden. Vatten: tidskrift för vattenvård/Journal of Water Management and Research 73(1-2):39-48

Lindner BL, Neuhauser A (2018) Climatology and variability of tropical cyclones affecting Charleston, South Carolina. J Coastal Res 34: 1052-1064

Lithgow D, Martínez ML, Gallego-Fernández JB, Hesp PA, Flores P, Gachuz S, Rodríguez-Revelo N, Jiménez-Orocio O, MendozaGonzález G, Álvarez-Molina LL (2013) Linking restoration ecology with coastal dune restoration. Geomorphology 199:214-224

Malavasi M, Santoro R, Cutini M, Acosta ATR, Carranza ML (2013) What has happened to coastal dunes in the last half century? A multitemporal coastal landscape analysis in Central Italy. Landsc Urban Plan 119:54-63

Malavasi M, Santoro R, Cutini M, Acosta ATR, Carranza ML (2016) The impact of human pressure on landscape patterns and plant species richness in Mediterranean coastal dunes. Plant Biosyst 150:73-82

Martínez LM, Gallego-Fernández JB, Hesp PA (2013) Restoration of coastal dunes, springer series on environmental management. Springer-Verlag, Berlin

Masselink G, Castelle B, Scott T, Dodet G, Suanez S, Jackson D, Floc'h F (2016) Extreme wave activity during 2013/2014 winter and morphological impacts along the Atlantic coast of Europe. Geophys Res Lett 43:2135-2143

Mathew S, Davidson-Arnott RGD, Ollerhead J (2010) Evolution of a beach-dune system following a catastrophic storm overwash event: Greenwich dunes, Prince Edward Island, 1936-2005. Can J Earth Sci 47:273-290

Maun MA (2009) The biology of coastal sand dunes. Oxford University Press, Oxford

Maximiliano-Córdova C, Salgado K, Martínez ML, Mendoza E, Silva R, Guevara R, Feagin RA (2019) Does the functional richness of plants reduce wave erosion on embryo coastal dunes? Estuar Coast:1-12

Millett J, Edmondson S (2013) The impact of 36 years of grazing management on vegetation dynamics in dune slacks. J Appl Ecol 50: $1367-1376$

Miot da Silva G, Hesp PA, Keim B, Martinho CT, Ferligoj Y (2013) Changes in dunefield geomorphology and vegetation cover as a response to local and regional climate variations. J Coast Res 65: $1307-1312$

Muñoz-Reinoso JC (2018) Doñana mobile dunes: what is the vegetation pattern telling us? J Coast Conserv 22:605-614

Moulton MA, Hesp PA, Miot da Silva G, Bouchez C, Lavy M, Fernandez GB (2019) Changes in vegetation cover on the Younghusband peninsula transgressive dunefields (Australia) 1949-2017. Earth Surf Process Landf 44:459-470

Murphy AL, Singers NJ, Rapson GL (2019) Created dune slack wetlands effectively host rare early successional turf communities in a dynamic dunefield, New Zealand. J Coast Conserv 23:203-225
Natural England (2018) Threatened sand dunes given a new lease of LIFE. Retrieved from: https://www.gov.uk/government/news/ threatened-sand-dunes-given-a-new-lease-of-life

Natural Resources Wales (2014) Restoring Newborough's sand dunes. Retrieved from: https://naturalresources.wales/about-us/news-andevents/news/restoring-newborough-s-sand-dunes/?lang=en

Nordstrom KF (2003) Beaches and dunes of developed coasts. Cambridge University Press

Nordstrom KF (2008) Beach and dune restoration. Cambridge University Press

Nordstrom KF, Jackson NL (2013) Foredune restoration in urban settings. In: Martínez ML, Gallego-Fernández JB, Hesp PA (eds) Restoration of coastal dunes, Springer series on environmental management. Springer-Verlag, Berlin, pp 17-31

Nordstrom KF, Psuty N, Carter B (1990) Coastal dunes: form and process, Wiley

Osswald F, Dolch T, Reise K (2019) Remobilizing stabilized island dunes for keeping up with sea level rise? J Coast Conserv 1-13

Paskoff R (2001) Dune management on the Atlantic coast of France: a case study. In: Houston JA, Edmondson SE, Rooney PJ (eds) Coastal dune management. Shared experience of European conservation practice. Proceedings of the European Symposium Coastal Dunes of the Atlantic Biogeographical Region, Southport, NW England, September 1998, Liverpool University Press, pp 125-143

Pérez-Maqueo O, Martínez ML, Nahuacatl RC (2017) Is the protection of beach and dune vegetation compatible with tourism? Tour Manag $58: 175-183$

Pickart AJ (2013) Dune restoration over two decades at the Lanphere and Ma-le'l Dunes in northern California. In: Martínez ML, GallegoFernández JB, Hesp PA (eds) Restoration of coastal dunes, Springer series on environmental management. Springer-Verlag, Berlin, pp 159-171

Pickart AJ, Hesp PA (2019) Spatio-temporal geomorphological and ecological evolution of a transgressive dunefield system, northern California, USA. Global Planet Change 172:88-103

Plassmann K, Jones MLM, Edwards-Jones G (2010) Effects of long-term grazing management on sand dune vegetation of high conservation interest. Appl Veg Sci 13:100-112

Pontee N (2013) Defining coastal squeeze: a discussion. Ocean Coast Manage 84:204-207

Provoost S, Jones MLM, Edmondson SE (2011) Changes in landscape and vegetation of coastal dunes in Northwest Europe: a review. J Coast Conserv 15:207-226

Provoost S, van Landuyt W (2001) The flora of the Flemish coastal dunes (Belgium) in a changing landscape. In: Houston JA, Edmondson SE, Rooney PJ (eds) Coastal dune management. Shared experience of European conservation practice. Proceedings of the European Symposium Coastal Dunes of the Atlantic Biogeographical Region, Southport, NW England, September 1998, Liverpool University Press, pp 393-401

Pye K, Blott SJ (2013) Kenfig phase 1 Dune rejuvenation works - overview report, July 2013. NRW evidence report series no: 43, 38pp, Natural Resources Wales

Pye K, Blott SJ (2016a) Assessment of beach and dune erosion and accretion using LiDAR: impact of the stormy 2013-14 winter and longer term trends on the Sefton coast, UK. Geomorphology 266: 146-167

Pye K, Blott SJ (2016b) Dune rejuvenation trials overview report. NRW evidence report series report no: 296, 140pp, Natural Resources Wales

Pye K, Blott SJ (2017) Evolution of a sediment-starved, over-stabilised dunefield: Kenfig burrows, South Wales, UK. J Coast Conserv 21: 685-717

Pye K, Blott SJ, Howe MA (2014) Coastal dune stabilization in Wales and requirements for rejuvenation. J Coast Conserv 18:27-54 
Ranwell DS (1960a) Newborough Warren, Anglesey II: plant associes and succession cycles of the sand dune and dune slack vegetation. $\mathrm{J}$ Ecol 48:117-141

Ranwell DS (1960b) Newborough Warren, Anglesey: III Changes in the vegetation on parts of the dune system after the loss of rabbits by myxomatosis. J Ecol 48:385-395

Reed DJ, Davidson-Arnott R, Perillo GME (2009) Estuaries, coastal marshes, tidal flats and coastal dunes. In: Slaymaker O, Spencer T, Embleton-Hamann C (eds) Geomorphology and global environmental change. Cambridge University Press

Rhind PM, Blackstock TH, Hardy HS, Jones RE, Sandison W (2001) The evolution of Newborough Warren dune system with particular reference to the past four decades. In: Houston JA, Edmondson SE, Rooney PJ (eds) Coastal dune management. Shared experience of European conservation practice. Proceedings of the European Symposium Coastal Dunes of the Atlantic Biogeographical Region, Southport, NW England, September 1998, Liverpool University Press, pp 345-379

Rhind PM, Jones PS (1999) The floristics and conservation status of sand-dune communities in Wales. J Coast Conserv 5:31-42

Rhind PM, Jones RE (2009) A framework for the management of sand dune systems in Wales. J Coast Conserv 13:15-23

Rhind P, Jones RE, Jones L (2013) The impact of dune stabilization on the conservation status of sand dune systems in Wales. In: Martínez ML, Gallego-Fernández JB, Hesp PA (eds) Restoration of coastal dunes, Springer series on environmental management. SpringerVerlag, Berlin, pp 125-143

Richards EG, Burningham H (2011) Hippophae rhamnoides on a coastal dune system: a thorny issue? J Coast Conserv 15:73-85

Rodgers S, O'Keeffe N, Delgado-Fernandez I (2019) Factors affecting dune mobility in Newborough, Wales. In Durán R, Guillén J, Simarro G (eds) Proceedings of the X Jornadas de Geomorfología Litoral, Castelldefels 4-6 September 2019, 129-132

Ruessink BG, Arens SM, Kuipers M, Donker JJA (2018) Coastal dune dynamics in response to excavated foredune notches. Aeolian Res 31:3-17

Ruggerio P, Hacker S, Seabloom E, Zarnetske P (2018) The role of vegetation in determining dune morphology, exposure to sea-level rise, and storm-induced coastal hazards: a Pacific northwest perspective. In: Moore L, Murray A (eds) Barrier dynamics and responses to changing climate. Springer, Cham

Seabloom EW, Williams JW, Slayback D, Stoms DM, Viers J, Hand Dobson AP (2006) Human impacts, plant invasion, and imperiled, plant species in California. Ecol Appl 16:1338-1350

Sherman DJ, Bauer BO (1993) Dynamics of beach-dune systems. Prog Phys Geogr 17:413-447
Sigren JM, Figlus J, Armitage AR (2014) Coastal sand dunes and dune vegetation: restoration, erosion, and storm protection. Shore Beach $82: 5-12$

Smith PH (2009) The sands of time revisited: an introduction to the sanddunes of the Sefton coast. Amberley Publishing, Stroud

Stevens CJ, Duprè C, Dorland E, Gaudnik C, Gowing DJG, Bleeker A, Diekmann M, Alard D, Bobbink R, Flower D, Corcket E, Mountford O, Vandvik V, Aarrestad PA, Muller S, Dise NB (2010) Nitrogen deposition threatens species richness of grasslands across Europe. Environ Pollut 158:2940-2945

Ten Harkel MJ (1996) The effects of particle-size distribution and chloride depletion of sea-salt aerosols on estimating atmospheric deposition at a coastal site. Atmos Environ 31(3):417-427

Terlouw L, Slings R (2005) Dynamic dune management in practiceremobilization of coastal dunes in the National Park ZuidKennemerland in the Netherlands. In: Herrier J-L, Mees A, Salman J, Seys H, Van Nieuwenhuyse H, Dobbelaere I (eds) Proceedings 'dunes and estuaries 2005' international conference on nature restoration practices in European coastal habitats, September 2005, Koksijde, Belgium, pp 211-217

Tsoar H (2005) Sand dunes mobility and stability in relation to climate. Physica A: Statistical Mechanics and its Applications 357(1):50-56

Van Boxel JH, Jungerius PD, Kieffer N, Hampele N (1997) Ecological effects of reactivation of artificially stabilized blowouts in coastal dunes. J Coast Conserv 3:57

Walker IJ, Davidson-Arnott RGD, Bauer BO, Hesp PA, DelgadoFernandez I, Ollerhead J, Smyth TAG (2017) Scale-dependent perspectives on the geomorphology of beach-dune systems. Earth-Sci Rev 171:220-253

Wouters B, Nijssen M, Geerling G, Van Kleef H, Remke E, Verberk W (2012) The effects of shifting vegetation mosaics on habitat suitability for coastal dune fauna - a case study on sand lizards (Lacerta agilis). J Coast Conserv 16:89-99

Yizhaq H, Ashkenazy Y, Tsoar H (2009) Sand dune dynamics and climate change: a modeling approach. J Geophys Res-Earth 114(F1)

Zarnetske PL, Seabloom EW, Hacker SD (2010) Non-target effects of invasive species management: beachgrass, birds, and bulldozers in coastal dunes. Ecosphere 1(5):1-20

Zoladeski CA (1991) Vegetation zonation in dune slacks on the Leba Bar, polish Baltic Sea coast. J Veg Sci 2:255-258

Zunzunegui M, Esquivias MP, Oppo F, Gallego-Fernández JB (2012) Interspecific competition and livestock disturbance control the spatial patterns of two coastal dune shrubs. Plant Soil 354:299-309

Publisher's note Springer Nature remains neutral with regard to jurisdictional claims in published maps and institutional affiliations. 